\title{
Identification of Resistance to Pod Fly, Melanagromyza obtusa (Malloch) infestation in Pigeonpea Genotypes Evaluated in the Field Experiment
}

\author{
T. N. Vijay Kumar*, C. P. Srivastava, Sabuj Ganguly and Saswati Premkumari \\ Department of Entomology and Agricultural Zoology, Institute of Agricultural Sciences, \\ Banaras Hindu University, Varanasi-221005, India \\ *Corresponding author
}

\begin{tabular}{l} 
K e y w o r d s \\
Pigeonpea, \\
Genotype, Pod fly, \\
Resistance, \\
Susceptible, \\
Damage \\
\hline Article Info \\
$\begin{array}{l}\text { Accepted: } \\
18 \text { August } 2020 \\
\text { Available Online: } \\
\text { 10 September } 2020\end{array}$ \\
\hline
\end{tabular}

A B S T R A C T

Resistance against insect pests is a crucial trait for the stability and sustainability of pigeonpea production. A field trail was conducted to quantify relative tolerance and sensitivity in9 new long duration pigeonpea genotypes including local control against pod fly during Kharif2017-18 at the Entomological Research Farm, Institute of Agricultural Sciences, Banaras Hindu University, Varanasi. In general, it was observed that none of the genotypes were found completely resistant to pests although these originated as least susceptible, moderately susceptible and highly susceptible. Of them, JKM 189 was rated as more tolerant to pod fly attack in comparison to Bahar (check) that appeared susceptible. The mean populations of pod fly among the genotypes ranged from 1.65 pod fly maggots/ plant in JKM 189 to 2.18 pod fly maggots/plant in Bahar (check). On the basis of per cent pod and grain damage values, the genotype JKM 189, CRG 2015-007 and LRG 208 less pest pressure than Bahar, BDN 2014-2 and BAUPP 15-22 which were the most susceptible. Differences in grain yield were also observed, indicating that minimal and maximal pest injury on pigeonpea influenced the crop yield. The genotypes JKM 189, CRG 2015-007and LRG 208 performed well in respect of higher grain yield. The results suggest that tolerant pigeonpea genotypes might be commercially cultivated extensively in this agro-climatic area and Scientists involving in development of host plant resistant cultivars are encouraged to utilize resistance sources as donar against key pest species.

\section{Introduction}

Pigeonpea [Cajanus cajan (L.) Millsp.] commonly known as Arhar or redgram or Tur in India. It belongs to the genus Cajanus of the sub-tribe Cajaninae, tribe Phaseolae under the family Leguminosae. The ability of redgram to produce high economic yields under soil moisture deficit makes it an important crop in rainfed and dryland agriculture. India contributes for nearly $90 \%$ of world's total redgram production. Worldwide, pigeonpea production averaged 4.89 million tons in 2014. In India Pigeonpea area was reported as 45.82 lakh ha with a production of 3.68 million tons in 2018-2019 (Directorate of Economics and Statistics DES). In India, major redgram producing states are Maharashtra (12.34 lakh ha), Karnataka (9.92 lakh ha), Madhya Pradesh 
(6.35 lakh ha), Uttar Pradesh (3.46 lakh ha), Telangana (2.77 lakh ha) and Gujarat (2.52 lakh ha). The productivity has always been a first and for most concern for the farmers. The low productivity of pigeonpea in the country may be attributed to many reasons, among which damage caused by the insect pests is of paramount importance (Mishra et al., 2012). More than 250 insect species have been recorded to attack pigeonpea (Anonymous, 2005). However, most damaging pests of pigeonpea are pod borers which attack the reproductive parts of the plant. Among thepod borers, pigeonpea pod fly, Melanagromyza obtusa (Malloch) is a more serious pest and infest 12 to 100 per cent pods causing losses of 2.4 to 95.0 per cent on seed and 2,50,000 tonnes by weight (Anonymous, 2014). In India, pigeonpea pods are available in the field from approximately October to April, and infestations increase rapidly over a relatively short period. Fewer eggs are laid in December and January when temperatures are low. Populations increase as temperatures rise. Long-duration Pigeonpea crops which mature in March or April can be heavily damaged (Shanower et al., 1999). Females copulate within 24 hours after emergence and oviposition quickly follows (Spencer KA, 1976). The female pod fly inserts its eggs inside the pod wall. Females produce up to 80 eggs and lay them individually in developing Pigeonpea pods (Shanower et al., 1999). After hatching, the young larvae initially feed on the seed surface of soft pigeonpea seeds. Later, they mine into the developing seeds and these mines change into deep galleries and the seeds become unfit for human consumption and germination (Lal et al., 1994). Before pupating, the full-grown larvae come out of the seeds and eat partial holes into the walls of the pods to enable the emerging flies to escape. The holes do not communicate with the exterior; each hole retains a thin, circular layer of epidermis. In a survey conducted by (ICRISAT, 2012) $M$. obtuse is reported to cause 22.5 per cent damage to Pigeonpea pods in north India, 21 per cent in central India and 13.2 per cent in south India (Lateef and Reed, 1981). In U.P. the annual loss in Pigeonpea production due to pod fly alone has been estimated to the extent of 25 to 30 per cent (Lal and Sachan, 1991). The host plant resistance to insect pests for restraining pest damage or their populations has been tremendously victorious practice. The host plant resistance of the crops presumes a vital part in pest management in order to boost productivity of plant (Sarwar $e t$ al., 2009; 2011) Thus, keeping these views in mind, the present study was conducted to identify resistant source to evolve long duration cultivars that became less susceptible to pod fly in pigeonpea.

\section{Materials and Methods}

The present investigation was carried out at Entomological Research Farm, Institute of Agricultural Sciences, Banaras Hindu University, Varanasi, India during Kharif, 2017-18 to evaluate the 9 long duration Pigeonpea genotypes including the control long duration variety [LRG 208, ICPL 87119, CRG 2015-007, BDN 2014-2, RKPV 455-02, BAUPP 15-22, JKM 189, RKPV 310-09 and Bahar (control)] against pigeonpea pod fly, Melanagromyza obtusa (Malloch). All these genotypes were grown in plots and in each plot contains of 3 rows of $4 \mathrm{~m}$ length following row to row and plant to plant spacing of $75 \mathrm{~cm}$ and $25 \mathrm{~cm}$ respectively. The crop was grown following the normal agronomic practices in "Randomized Block Design (RBD)" with three replications. The crop was sown on $22^{\text {nd }}$ July 2017 and harvested on $15^{\text {th }}$ April 2018 respectively. The population of pod fly was recorded by observing 5 plants selected randomly out of 100 pods picked up from 5 selected plants in each treatment. The number of insect count recorded from all the three replications and 
for all the genotypes were averaged separately for each genotype on standard week basis.

The sampling for pod and seed damage assessment due to pod fly was done at $80 \%$ maturity stage of the crop. For per cent pod and grain damage assessment, five plants from the three central rows in each plot were selected randomly and all the pods from five plants were pooled together and finally 100pods were picked up and observations were recorded. Later, the percent pod and grain damage was also calculated and recorded. The grain yield was also recorded for each plot after excluding the border rows on the two sides of the plot and then extrapolated into $\mathrm{kg} / \mathrm{ha}$.

\section{Data analysis}

Prior to statistical analysis, all data on insect pests counts and percentages of damage were transformed to mean values, analyzed statistically and mean population data were transformed with square root transformation $\square \mathrm{x}+0.5$ method and damageassessment data were transformed by $\operatorname{arc} \sin (\mathrm{q}=\sin 1 \mathrm{x})$ transformation method.

\section{Results and Discussion}

\section{Incidence pattern and population dynamics of M. obtusa}

On the whole, it was observed that the incidence of pest population was varied significantly from all genotypes. The first incidence of pod fly was observed in the $4^{\text {th }}$ standard week on 24th January in all genotypes (Table 1) and the population persisted up to 12th standard week in all the genotypes. The peak population of pod fly irrespective of the genotype was in 11th standard week (4 maggots/plant) and thereafter, it was declined due to maturity of the grains. The mean populations of pod fly on different genotypes differed significantly and ranged from 1.65 pod fly maggots/plant in JKM 189 to 2.18 pod fly maggots/plant in Bahar (control). The results are in agreement with (Kumar and Nath, 2003) who reported that the activity of pod fly (Melanagromyza obtusa) infestation was observed from 23rd January to 8th April. Its peak population was recorded on 22nd February. The present findings are also in agreements to the reports of (Jaisal et al., 2010). Srujana and Keval in the year 2014, also studied seasonal incidence pattern of tur pod fly on long duration pigeon pea (Bahar). Highest mean population of $M$. obtusawas observed in 9th standard week (7.0 maggots/ 10 pods), followed by 12 th standard week (6.8 maggots/ 10 pods) and lowest population (0.8 maggots/ 10 pods) was recorded in the 1st standard week (Figure 1).

\section{Extent of pod damage caused by M. obtusa}

The per cent pod damage caused by pod fly on different genotypes varied significantly (Table 2). It ranged from 27.66 per cent in genotype JKM 189 to 38.66 per cent in genotype Bahar (check). Damage due to pod fly were seen in Bahar (38.66 \%) followed by BDN 2014 (34.33\%) and BAUPP 15-22 $(31.00 \%)$ and lowest pod damage was observed in JKM 189 (27.66\%) followed by CRG 2015-007 (28.33\%) and LRG 208 (28.66\%).

Srivastava and Mohapatra (2002) reported that the extent of pod damage inflicted by lepidopteran pod borers and pod fly on fifteen pigeonpea genotypes varied from 1.0 to 6.3 per cent and 15.1 to 33.1 per cent, respectively. On the basis of pooled mean, two lines viz., JKM 189 (27.66\%) and CRG 2015-007 (28.33\%) revealed resistance against the pod damage caused by pod fly, respectively (Fig. 2). 
Table.1 Maggot population of pod fly (Melanagromyza obtusa Malloch) on long duration pigeonpea genotypes during 2017-18

\begin{tabular}{|c|c|c|c|c|c|c|c|c|c|c|}
\hline \multirow[b]{2}{*}{ Genotypes } & \multicolumn{10}{|c|}{ Pod fly maggot per plant } \\
\hline & $4^{\text {th }} \mathrm{SW}$ & $5^{\text {th }} \mathrm{SW}$ & $6^{\text {th }} \mathrm{SW}$ & $7^{\text {th }} \mathrm{SW}$ & $8^{\text {th }} \mathrm{SW}$ & $9^{\text {th }}$ SW & $10^{\text {th }} \mathrm{SW}$ & $11^{\text {th }} \mathrm{SW}$ & $12^{\text {th }} \mathrm{SW}$ & $\begin{array}{c}\text { Over all } \\
\text { mean }\end{array}$ \\
\hline LRG 208 & $\begin{array}{c}1.20 \\
(1.483)\end{array}$ & $\begin{array}{c}1.36 \\
(1.536)\end{array}$ & $\begin{array}{c}1.44 \\
(1.561)\end{array}$ & $\begin{array}{c}1.76 \\
(1.661)\end{array}$ & $\begin{array}{c}1.77 \\
(1.664)\end{array}$ & $\begin{array}{c}1.80 \\
(1.673)\end{array}$ & $\begin{array}{c}1.82 \\
(1.679)\end{array}$ & $\begin{array}{c}2.36 \\
(1.883)\end{array}$ & $\begin{array}{c}1.96 \\
(1.720)\end{array}$ & $\begin{array}{c}1.72 \\
(1.650)\end{array}$ \\
\hline ICPL 87119 & $\begin{array}{c}1.22 \\
(1.490)\end{array}$ & $\begin{array}{c}1.46 \\
(1.568)\end{array}$ & $\begin{array}{c}1.52 \\
(1.587)\end{array}$ & $\begin{array}{c}1.79 \\
(1.670)\end{array}$ & $\begin{array}{c}1.85 \\
(1.688)\end{array}$ & $\begin{array}{c}2.48 \\
(1.865)\end{array}$ & $\begin{array}{c}1.78 \\
(1.667)\end{array}$ & $\begin{array}{c}2.40 \\
(1.844)\end{array}$ & $\begin{array}{c}2.00 \\
(1.728)\end{array}$ & $\begin{array}{c}1.78 \\
(1.668)\end{array}$ \\
\hline CRG 2015-007 & $\begin{array}{c}1.20 \\
(1.1 .483)\end{array}$ & $\begin{array}{c}1.35 \\
(1.533)\end{array}$ & $\begin{array}{c}1.37 \\
(1.539)\end{array}$ & $\begin{array}{c}1.78 \\
(1.667)\end{array}$ & $\begin{array}{c}1.80 \\
(1.673)\end{array}$ & $\begin{array}{c}1.86 \\
(1.691)\end{array}$ & $\begin{array}{c}1.90 \\
(1.703)\end{array}$ & $\begin{array}{c}2.25 \\
(1.803)\end{array}$ & $\begin{array}{c}1.91 \\
(1.706)\end{array}$ & $\begin{array}{c}1.71 \\
(1.646)\end{array}$ \\
\hline BDN 2014-2 & $\begin{array}{c}1.35 \\
(1.543)\end{array}$ & $\begin{array}{c}1.45 \\
(1.565)\end{array}$ & $\begin{array}{c}1.69 \\
(1.640)\end{array}$ & $\begin{array}{c}1.91 \\
(1.706)\end{array}$ & $\begin{array}{c}1.94 \\
(1.715)\end{array}$ & $\begin{array}{c}2.00 \\
(1.728)\end{array}$ & $\begin{array}{c}2.62 \\
(1.903)\end{array}$ & $\begin{array}{c}3.30 \\
(2.071)\end{array}$ & $\begin{array}{c}2.50 \\
(1.868)\end{array}$ & $\begin{array}{c}2.10 \\
(1.761)\end{array}$ \\
\hline RKPV 455-02 & $\begin{array}{c}1.34 \\
(1.530)\end{array}$ & $\begin{array}{c}1.40 \\
(1.549)\end{array}$ & $\begin{array}{c}1.49 \\
(1.578)\end{array}$ & $\begin{array}{c}1.60 \\
(1.611)\end{array}$ & $\begin{array}{c}1.92 \\
(1.709)\end{array}$ & $\begin{array}{c}2.20 \\
(1.788)\end{array}$ & $\begin{array}{c}2.10 \\
(1.761)\end{array}$ & $\begin{array}{c}2.50 \\
(1.870)\end{array}$ & $\begin{array}{c}2.10 \\
(1.758)\end{array}$ & $\begin{array}{c}1.80 \\
(1.672)\end{array}$ \\
\hline BAUPP 15-22 & $\begin{array}{c}1.20 \\
(1.483)\end{array}$ & $\begin{array}{c}1.48 \\
(1.575)\end{array}$ & $\begin{array}{c}1.79 \\
(1.670)\end{array}$ & $\begin{array}{c}1.87 \\
(1.694)\end{array}$ & $\begin{array}{c}1.90 \\
(1.700)\end{array}$ & $\begin{array}{c}1.99 \\
(1.729)\end{array}$ & $\begin{array}{c}2.42 \\
(1.849)\end{array}$ & $\begin{array}{c}2.40 \\
(1.844)\end{array}$ & $\begin{array}{c}2.00 \\
(1.731)\end{array}$ & $\begin{array}{c}1.87 \\
(1.695)\end{array}$ \\
\hline $\begin{array}{c}\text { BAHAR } \\
\text { (Check) }\end{array}$ & $\begin{array}{c}1.38 \\
(1.533)\end{array}$ & $\begin{array}{c}1.50 \\
(1.581)\end{array}$ & $\begin{array}{c}1.60 \\
(1.612)\end{array}$ & $\begin{array}{c}1.80 \\
(1.673)\end{array}$ & $\begin{array}{c}2.10 \\
(1.760)\end{array}$ & $\begin{array}{c}2.90 \\
(2.212)\end{array}$ & $\begin{array}{c}2.85 \\
(1.962)\end{array}$ & $\begin{array}{c}3.43 \\
(2.104)\end{array}$ & $\begin{array}{c}2.55 \\
(1.883)\end{array}$ & $\begin{array}{c}2.18 \\
(1.783)\end{array}$ \\
\hline SEm \pm & 0.006 & 0.015 & 0.013 & 0.018 & 0.02 & 0.028 & 0.014 & 0.016 & 0.005 & 0.013 \\
\hline CD at $5 \%$ & 0.019 & 0.045 & 0.041 & 0.054 & 0.061 & 0.084 & 0.041 & 0.047 & 0.015 & 0.040 \\
\hline
\end{tabular}

Figures in parentheses are $\sqrt{\mathrm{x}}+0.5$ transformed value SW: Standard week 
Table.2 Extent of pod and grain damage caused by pod fly [Melanagromyza obtusa (Malloch)] on long duration pigeonpea genotypes during 2017-18

\begin{tabular}{|c|c|c|c|}
\hline Sl. No. & GENOTYPES & $\begin{array}{c}\text { Per cent pod damage } \\
\text { by } \boldsymbol{M} \text {. obtusa }\end{array}$ & $\begin{array}{c}\text { Per cent grain damage by } \\
\text { M. obtusa }\end{array}$ \\
\hline $\mathbf{1}$ & LRG 208 & $28.66(32.33)$ & $13.37(20.52)$ \\
\hline $\mathbf{2}$ & ICPL 87119 & $29.00(32.41)$ & $13.53(20.79)$ \\
\hline $\mathbf{3}$ & CRG 2015-007 & $28.33(32.12)$ & $12.10(21.46)$ \\
\hline $\mathbf{4}$ & BDN 2014-2 & $34.33(35.84)$ & $15.05(21.46)$ \\
\hline $\mathbf{5}$ & RKPV 455-02 & $30.66(33.58)$ & $14.33(22.18)$ \\
\hline $\mathbf{6}$ & BAUPP 15-22 & $31.00(33.81)$ & $14.69(21.63)$ \\
\hline $\mathbf{7}$ & JKM 189 & $27.66(31.57)$ & $8.01(15.71)$ \\
\hline $\mathbf{8}$ & RKPV 310-09 & $30.66(33.58)$ & $14.53(21.63)$ \\
\hline $\mathbf{9}$ & BAHAR(Check) & $38.66(39.91)$ & $16.95(23.86)$ \\
\hline & SEm \pm & 2.76 & 1.18 \\
\hline & CD at 5\% & 7.77 & 4.85 \\
\hline
\end{tabular}

Table.3 Yield of different long duration pigeonpea genotypes during 2017-18

\begin{tabular}{|c|c|c|}
\hline Sl. No. & Genotypes & Yield kg/ha \\
\hline $\mathbf{1}$ & LRG 208 & 1179 \\
\hline $\mathbf{2}$ & ICPL 87119 & 1083 \\
\hline $\mathbf{3}$ & CRG 2015-007 & 1250 \\
\hline $\mathbf{4}$ & BDN 2014-2 & 927 \\
\hline $\mathbf{5}$ & RKPV 455-02 & 1049 \\
\hline $\mathbf{6}$ & BAUPP 15-22 & 1013 \\
\hline $\mathbf{7}$ & JKM 189 & 1500 \\
\hline $\mathbf{8}$ & RKPV 310-09 & 1092 \\
\hline $\mathbf{9}$ & BAHAR(Check) & 916 \\
\hline & SEm \pm & 1.18 \\
\hline & CD at 5\% & 4.85 \\
\hline
\end{tabular}


Figure.1 Average pod fly population per plant in different pigeonpea genotypes during 2017-18

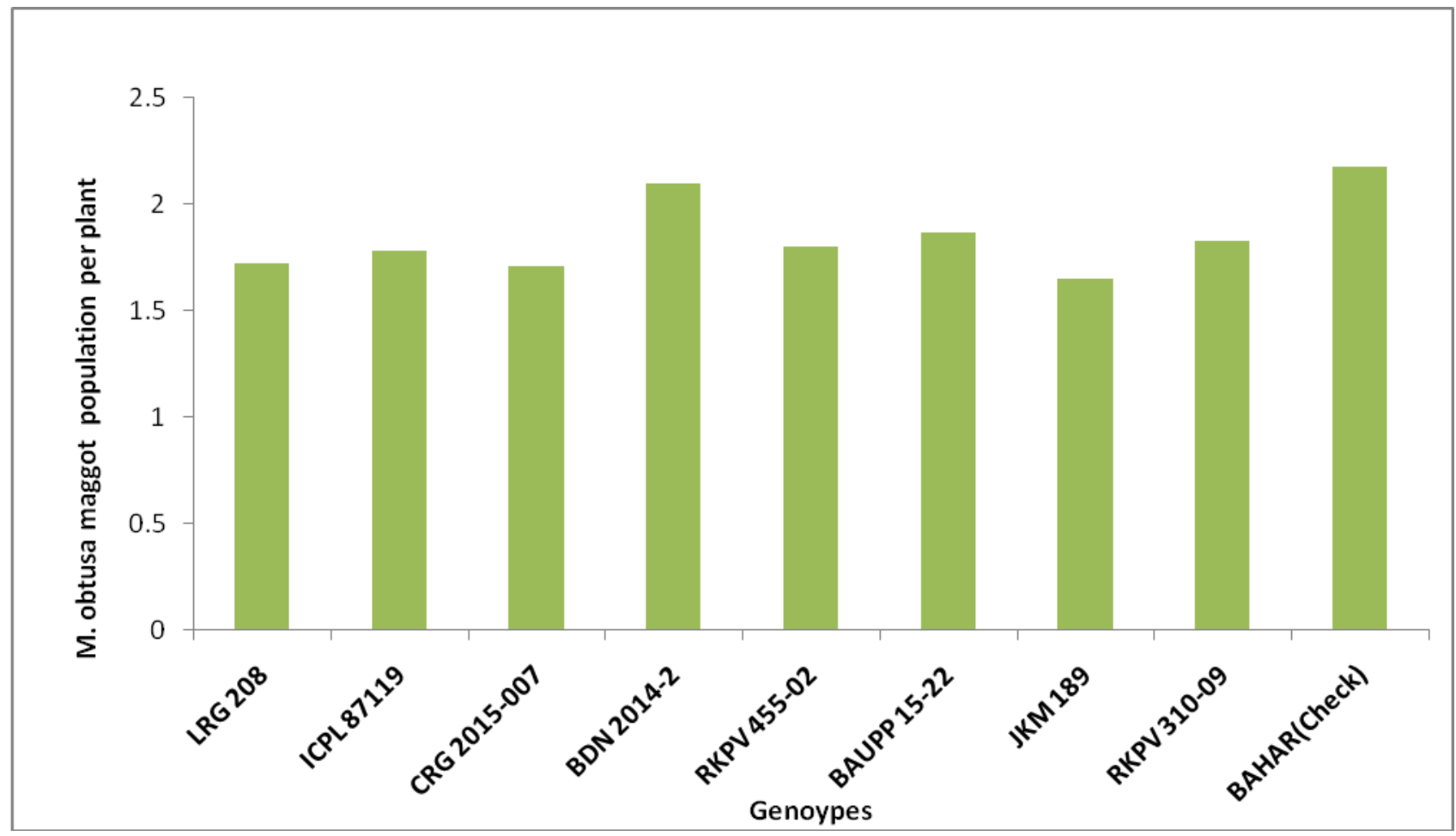

Figure.2 Average percentage of pod and grain damage in different pigeonpea genotypes during $2017-18$

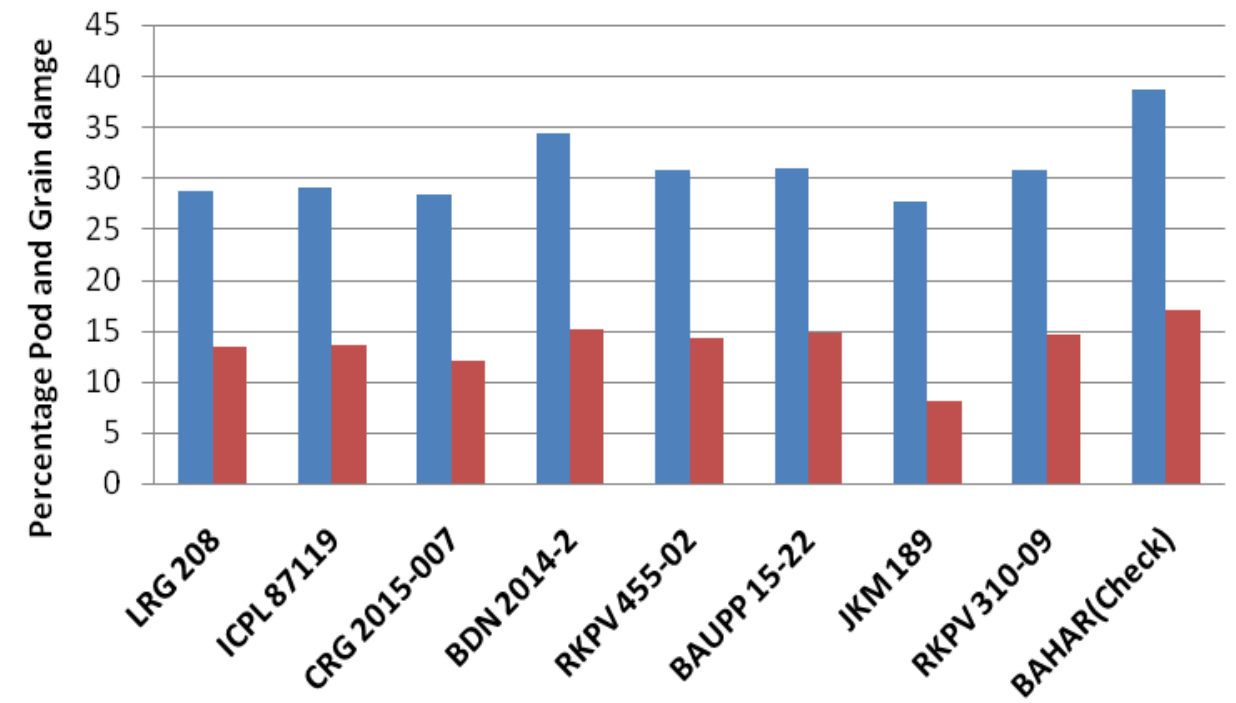

- Per cent pod damage by $\mathrm{M}$. obtusa

Per cent grain damage by $\mathrm{M}$. obtusa 
Figure.3 Tur pod fly (Melanagromyza obtusa Malloch) damaged Pods, damaged grains and pupa

Damaged pod
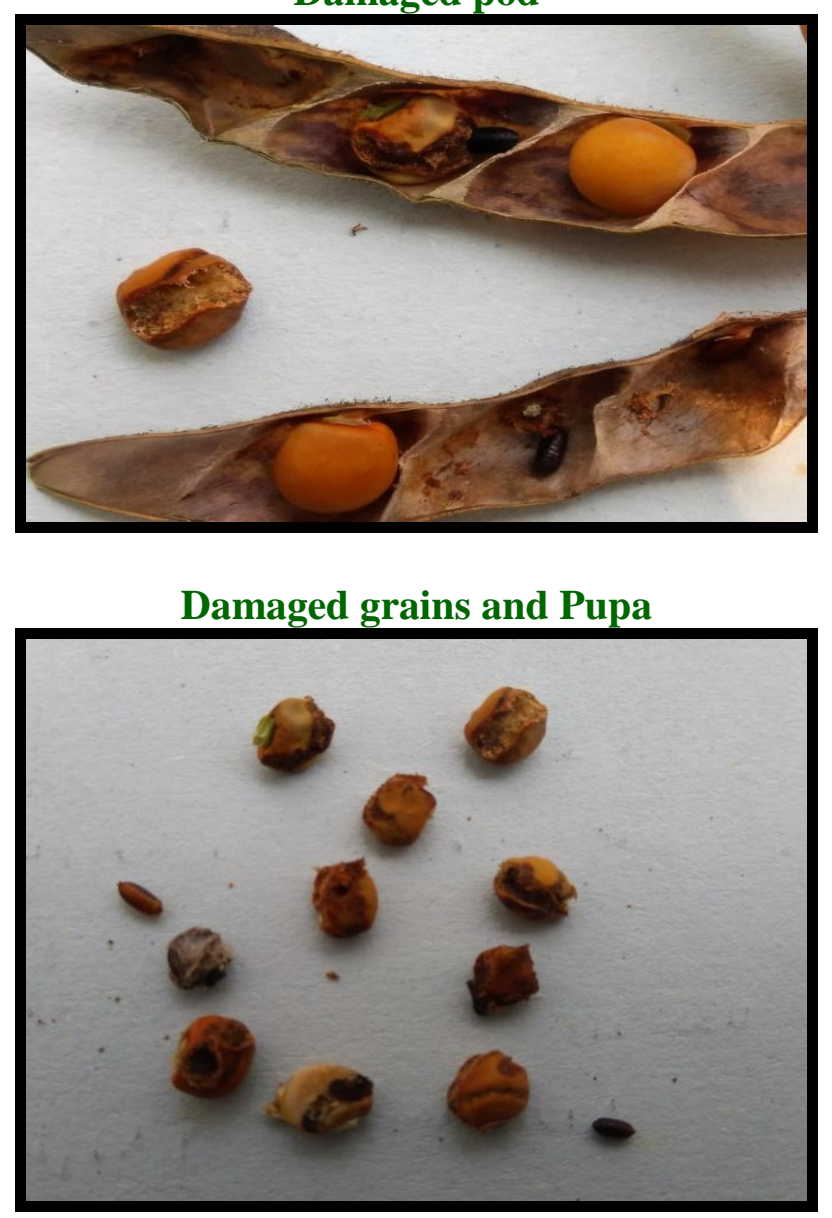

Extent of grain damage caused by $M$. obtuse

The per cent grain damage due to pod fly also showed significant difference among the genotypes (Table 2). It ranged from 8.01 per cent in genotype JKM 189 to 16.95 per cent in genotype Bahar (check). The highest grain damage by pod fly were seen in Bahar (16.95 $\%)$ followed by BDN 2014-2 (15.05\%) and BAUPP 15-22 (14.69\%) and lowest grain damage was observed in JKM $189(8.01 \%)$ followed by CRG 2015-007 (12.10\%) and LRG 208 (13.37 \%). (Mishra et al., 2012) reported that among the 50 pigeonpea germplasms, a wide range of variation of pod (18.33 to $47.00 \%$ ) and seed (16.43 to $48.44 \%$ ) damage by pod fly were recorded with average mean of 30.68 and $31.69 \%$, respectively. based on the pooled mean of two genotypes viz., JKM $189(8.01 \%)$ and CRG 2015-007 (12.10\%) were categorized as resistant against the grain damage caused by pod fly. This may be due to difference in susceptibility of genotypes to pod fly.

Various authors all over the country have rated the pod fly as the serious pest in northern part of India (Kumar et al., 1998, Sarwar et al., 2009 and 2011). The present 
finding corroborates with the findings of these authors (Fig. 3).

\section{Grain yield}

This investigation observed a significant difference in grain yield among the nine genotypes (Table 3). During the kharif 201718 season, the grain yield ranged from 1500 $\mathrm{kg} / \mathrm{ha}$ to $916 \mathrm{~kg} / \mathrm{ha}$. The highest grain yield was recorded in JKM 189 (1500 kg/ha) which was significantly different from other genotypes followed by CRG 2015-007 (1250 kg/ha),LRG 208 (1179 kg/ha), RKPV 310-09 $(1092 \mathrm{~kg} / \mathrm{ha})$ and lowest grain damage was observed in Bahar-check (916 kg/ha) followed by BDN 2014-2(927 kg/ha), BAUPP 15-22 (1013 kg/ha),RKPV 455-02 (1049 kg/ha) and ICPL 87119 (1083 kg/ha). These findings are in conformity with (Banu et al., 2007) and (Borad et al., 1991) reported higher yield potential in those pigeonpea genotypes which showed lesser incidence of pod borers.

In conclusion, the host plant resistance ranking is a management tool to help pigeonpea researchers and growers in choosing the best pigeonpea genotypes to plant in their environment by considering the risk for pests. These entire results are advantageous to give an insect resistant pigeonpea plants that might be of use in insect resistance management programs. From all these outcomes the average performance of pigeonpea genotypes for the entire considered characters are incredibly imperative to choose the most excellent and superior genotypes for using in general agriculture. Hence this experiment concluded that JKM 189 and CRG 2015-007 were found to be most tolerant genotypes against pod fly Melanagromyza obtuse (Malloch) damage and also recorded better yield. These results suggest that tolerant pigeonpea genotypes might be commercially cultivated extensively in this agro-climatic area.

\section{Acknowledgement}

Authors profoundly acknowledge to Institute of Agricultural Sciences, Banaras Hindu University (BHU), Varanasi and Dr. Ram Keval, for providing a continuous support and guidance during the period of research.

\section{References}

Anonymous, (2005). FAOSTAT Data. http:/www.faostat.fao.org/.

Association of pigeonpea against major insect pests in Northeastern Ghat zone.

Anonymous. (2014). Agricultural statistics at a glance, Department of Agriculture and Cooperation, Ministry of Agriculture, Government of India, p. 97.

Banu M R, Muthiah A R, Ashok S. (2007). Field screening and evaluation of pigeonpea genotypes against pod borer (Helicoverpa armigera). Pak. J. Biol. Sci. 10(7): 1149-1150.

Borad P K, Patel J R, Patel M G. (1991). Evaluation of vegetable pigeonpea genotypes resistance to gram pod borer, plume moth and pod fly. Indian J. Agric. Sci., 61: 682-684.

ICRISAT. 2012. http://www.icrisat.org (Accessed 26 May, 2014)

Jaisal J K, Srivastava C P. and Sharma R P. (2010). Resistance in long duration pigeonpea against major insect pests. Ann. Pl. Protec. Sci. 18(2): 501-502.

Kumar A. and Nath P. 2003. Pest complex and their population dynamics on medium-late variety of, Bahar. Indian J. Pulses Res.16(2): 150-154.

Kumar R, Ali S, Singh B B, Singh R K. and Kumar R. (1998). Screening of pigeonpea germplasm against turpodfly. Indian J. Pulses Res.11(1): 118-119.

Lal S S, Yadav C P. (1994) Ovipositional response of pod fly (Melanagromyza 
obtusa) on resistant pigeonpea (Cajanus cajan) selections. Indian J. of Agric. Sci. 64(9): 658-660.

Lal S S. and Sachan J N. (1991). Controlling pod fly, Melanagromyza obtuse in late pigeonpea through host-plant resistance. Int. Pigeonpea Newsl.15: 28-30.

Lateef S S. and Reed W. (1981). Survey of insect pest damage in farmer's field in India. Int. Pigeonpea Newsl.1: 29-30.

Minja E M, Silim S N. and Karuru O. (2000). Insect pest incidence on long-duration Uganda lines at Kabete in Kenya. Int. Chickpea Pigeonpea Newsl.7: 56-57.

Mishra M K, Singh R P. and Ali S. (2012). Chemical control and avoidable yield losses of pigeonpea due to insect pests. Ann. Pl. Protec. Sci. 20: 306309.

Reddy, C.N., Singh, Y. and Singh, V.S. 1998.Pest complex and their succession on variety $\mathrm{P}-33$. Indian J. Entomol., 60(4): 334-338.

Sarwar M, Ahmad N, Tofique M (2011). Identification of susceptible and tolerant gram (Cicer arietinum L.) genotypes against gram pod borer (Helicoverpa armigera) (Hubner).
Pakistan Journal of Botany, 43 (2): 1265-1270.

Sarwar M, Ahmad N, Tofique M (2009). Host plant resistance relationships in chickpea (Cicer arietinum L.) against gram pod borer Helicoverpa armigera) (Hubner). Pakistan Journal of Botany, 41 (6): 3047-3052.

Shanower T.G., Romeis J, Minja EM. Insect pests of pigeonpea and their management. Annual Review of Entomology. 1999; 44:77-96.

Shanower, T. G., Romeis, J. and Minja, E. M. (1999). Insect pests of pigeonpea and their management. Annual Review of Entomology. 44: 77-96.

Spencer KA. The Agromyzidae (Diptera) of economic importance. Series Entomologica. 1973; 9:i-xi+1-418.

Srivastava, C.P. and Mohapatra, S.D. 2002.Field screening of genotypes for resistance to major insect pests. $J$. App. Zool. Res., 13(2/3): 202-203.

Srujana, Y. and Kewal, R. 2014. Periodic occurrence and association of pod fly and pod bug on long duration pigeonpea (Bahar) with weather parameters. J. Exp. Zool., India, 17(2): 595-597.

\section{How to cite this article:}

Vijay Kumar, T.N., C. P. Srivastava, Sabuj Ganguly and Saswati Premkumari. 2020. Identification of Resistance to Pod Fly, Melanagromyza obtusa (Malloch) infestation in Pigeonpea Genotypes Evaluated in the Field Experiment. Int.J.Curr.Microbiol.App.Sci. 9(09): 2546-2554. doi: https://doi.org/10.20546/ijcmas.2020.909.319 